\title{
EFEKTIVITAS FERMENTASI AIR TEBU SEBAGAI BAHAN ATRAKTAN NYAMUK Aedes aegypti MENGGUNAKAN PERANGKAP NYAMUK DI LABORATORIUM ENTOMOLOGI JURUSAN KESEHATAN LINGKUNGAN PURWOKERTO TAHUN 2015
}

\author{
Dhani Nur Wijayanti' ${ }^{1)}$, Arif Widyanto ${ }^{2)}$ \\ Jurusan Kesehatan Lingkungan, Politeknik Kesehatan Kemenkes Semarang, \\ Jl.Raya Baturaden KM 12 Purwokerto, Indonesia
}

\begin{abstract}
Abstrak
Di Indonesia, epidemi Demam Berdarah Dengue (DBD) merupakan problem dan penyebab utama morbiditas dan mortalitas pada anak - anak. Penyakit Deman Berdarah Dengue (DBD) merupakan penyakit yang disebabkan oleh virus dengue dan ditularkan oleh Aedes aegypti dan Aedes albopictus. Penyebab DBD sampai saat ini masih menjadi salah satu masalah kesehatan masyarakat di indonesia.Tujuan penelitian ini adalah untuk mengetahui Efektivitas fermentasi air tebu guna menangkap nyamuk Aedes aegypti menggunakan perangkap nyamuk. Jenis penelitian yang digunakan adalah eksperimen dengan rancangan the randomized posttest only control group yang terdiri dari sampel dan kontrol. Hasilpenelitian konsentrasi $40 \%$ dapat dikatakan konsentrasi yang paling banyak mendapatkan jumlah nyamuk Aedes aegypti yang terperangkap. Simpulan penelitian ini adalah Konsetrasi fermentasi air tebu yang yang paling banyak mendapatkan jumlah nyamuk Aedes aegypti yang terperangkap adalah konsentrasi 40\%, karena paling banyak mendapatkan nyamuk yang terperangkap jika dibandingkan dengan konsentrasi yang lain.
\end{abstract}

Kata kunci : Nyamuk Aedes aegypti, Air tebu, Atraktan, Jurusan Kesehatan Lingkungan

\section{Abstract}

[The Fermented Sugarcane Essence Effectiveness as Aedes aegypti Mosquito Atractants in The Environmental Health Department Entomology Laboratory of Purwokerto Year of 2015] In Indonesia, the Dengue Hemorrhagic Fever (DHF) epidemic was the main problem and a major cause children morbidity and mortality. Dengue Hemorrhagic Fever (DHF) Diseases caused by the dengue virus and transmitted by Aedes aegypti and Aedes albopictus. The dengue main causes still remain a public health problem in Indonesia.. The research objective was determining the fermented sugarcane essence effectiveness as aedes aegypti mosquito attractants. The research method used was randomized experimental method with posttest only control group consisted samples and control. The research result shows that $40 \%$ concentration can be said to be concentration that trapped more Aedes aegypti mosquito compared with other concentration. The conclusions drawn was; there was no effective concentration, but when compared to other concentration, fermented sugarcane that trapped more Aedes aegypti mosquito trapped was the $40 \%$, concentration.

Keywords : Aedes aegypti Mosquito, Sugarcane Essence, attractant, environmental health

\section{PENDAHULUAN}

Salah satu yang menjadi masalah kesehatan masyarakat yang cenderung semakin luas penyebarannya, sejalan dengan meningkatnya arus transportasi dan kepadatan penduduk adalah penyakit Demam Berdarah Dengue (DBD). Penyakit ini ditemukan nyaris diseluruh belahan dunia terutama di negara tropik dan subtropik baik secara endemi maupun epidemi dengan outbreak yang berkaitan dengan datangnya musim penghujan.

Di Indonesia, epidemi Demam Berdarah Dengue (DBD) merupakan problem dan penyebab utama morbiditas dan mortalitas pada anak - anak. Penyakit Deman Berdarah Dengue (DBD) merupakan penyakit

1) Email : dhaninurwijayanti@gmail.com

2) Email : arifwidyanto74@yahoo.com yang disebabkan oleh virus dengue dan ditularkan oleh Aedes aegypti dan Aedes albopictus. Penyebab DBD sampai saat ini masih menjadi salah satu masalah kesehatan masyarakat di indonesia. Jumlah penderita dan luas daerah penyebarannya semakin bertambah seiring dengan meningkatnya mobilitas dan kepadatan penduduk ( Djoni Djunaedi, 2006, h.7)

Upaya pemberantasan terhadap penyakit DBD yang dilaksanakan saat ini adalah memutuskan mata rantai penularan yaitu dengan cara pengendalian vektornya. Secara teorotis ada empat cara untuk memutuskan mata rantai penularan penyakit DBD yaitu melenyapkan penyebab penyakit (Plasmodium), isolasi penderita, mencegah gigitan nyamuk (vektor) 
dan pengendalian vektor. Pengendalian vektor dapat dilaksanakan dengan lima cara yaitu pengendalian secara kimia, pengendalian secara biologis, pengelola lingkungan, pengendalian secara genetik, dan pengendalian secara terpadu. Pengendalian vektor dengan cara kimia antara lain dengan menggunakan insektisida, tetapi cara tersebut memiliki kekurangan yaitu : memerlukan dana yang tidak sedikit, mempunyai dampak negatif terhadap manusia dan lingkungan berupa penurunan kualitas tanah dan menyebabkan resisten pada organisme, mengingat dampak negatif tersebut maka perlu di cari alternatif insektisida dari tumbuhan atau insektisida nabati yang relatif ramah lingkungan.

Atraktan adalah sesuatu yang memiliki daya tarik terhadap serangga (nyamuk) baik secara kimiawi maupun visual (fisik). Atraktan dari bahan kimia dapat berupa senyawa amonia, $\mathrm{CO}_{2}$, asam laktat, octenol, dan asam lemak. Zat atau senyawa tersebut berasal dari bahan organik atau merupakan hasil proses metabolisme mahluk hidup, termasuk manusia. Atraktan fisika dapat berupa getaran suara dan warna, baik warna tempat atau cahaya. Atraktan dapat digunakan untuk mempengaruhi perilaku, memonitor atau menurunkan populasi nyamuk secara langsung, tanpa menyebabkan cidera bagi binatang lain dan manusia, dan tidak meninggalkan residu pada makanan atau bahan pangan. (Sayono, dkk, 2008).

Tanaman Tebu hanya di kenal di Indonesia. Di lingkungan Internasional tanaman ini lebih dikenal dengan nama ilmiahnya, Saccharatum officinarum $L$. Jenis ini termasuk dalam famili gramineae atau lebih di kenal sebagai kelompok rumput - rumputan. Secara morfologi, tanaman tebu dapat dibagi menjadi beberapa bagian, yaitu batang, daun, akar, dan bunga.

Tanaman Tebu apabila dipotong, akan terlihat serat - serat dan terdapat cairan yang manis. Serat dan kulit batang biasa di sebut dengan presentase sekitar $12,5 \%$ dari bobot tebu. Cairannya di sebut nira dengan presentase $87,5 \%$. Nira terdiri dari air dan bahan kering. (Sutadi, 1991,h. 24)

Cairan yang dihasilkan dari perasan tebu mengggandung glukosa dan dapat difermentasikan sebagai atraktan, ragi juga dapat digunakan dalam membantu mempercepat proses fermentasi, karena ragi mengandung jutaan sel hidup.

Ragi adalah mikroorganisme hidup yang dapat ditemukan dimana- mana. Ragi berasal dari keluarga Fungus bersel satu (sugar fungus) dari genus Saccharomyces, species cereviciae, dan memilki ukuran sebesar 6-8 mikron. Dan Saccharomyces cereviciae merupakan genom eukariotik yang pertama kali disekuensi secara penuh. Dalam satu gram ragi padat (compressed yeast) terdapat kurang lebih 10 milyar sel hidup. (Dwidjoseputro,1989,h.65) Fermentasi adalah proses produksi energi dalam sel dalam keadaan anaerobik (tanpa oksigen). Secara umum, fermentasi adalah salah satu bentuk respirasi anaerobik, akan tetapi, terdapat definisi yang lebih jelas yang mendefinisikan fermentasi sebagai respirasi dalam lingkungan anaerobik dengan tanpa ekseptor elektron eksternal. (Dwidjoseputro,1989,h.78)

Perangkap nyamuk merupakan salah satu alat yang digunakan untuk menangkap nyamuk, sehingga dapat mengurangi populasi nyamuk dewasa di suatu wilayah. Karena makanan nyamuk adalah madu dan sari buah, maka peneliti akan mencoba meneliti menggunakan larutan yang rasanya mirip dengan madu yaitu larutan tebu yang di masukan kedalam perangkap nyamuk dan di tambahkan dengan ragi bubuk. Maka akan di hasilkan $\mathrm{CO}_{2}$ dari proses fermentasi yang dapat menarik agar nyamuk menghampiri perangkap nyamuk tersebut.

Tujuan dari penelitian ini adalah mengetahui efektivitas fermentasi air tebu guna menangkap nyamuk Aedes aegypti menggunakan perangkap nyamuk.

\section{BAHAN DAN METODE}

Bahan yang digunakan dalam penelitian ini adalah nyamuk Aedes aegypti yang akan diketahui jumlahnya yang terperangkap dalam perangkap nyamuk yang berada di dalam kurungan nyamuk, perangkap nyamuk berisi fermentasi air tebudengan konsentrasi 5\%, 10\%, 20\%, 40\% dan 0\% (air bersih dan ragi sebagai kontrol). Metode yang digunakan adalah eksperimen dengan rancangan the randomized posttest only control group yang terdiri dari sampel dan kontrol. Cara pengumpulan data yang digunakan dalam penelitian ini adalah mengukur dan menghitung secara langsung terhadap obyek yang diteliti. Mengukur digunakan untuk mengetahui suhu dan kelembaban tempat penelitian, sedangkan menghitung digunakan untuk mengetahui banyaknya nyamuk Aedes aegypti yang terperangkap.

\section{III.HASIL DAN PEMBAHASAN}

Hasil dan pembahasan dari penelitian ini yaitu :

1. Suhu

Pengukuran suhu pada lokasi penelitian bertujuan untuk mengetahui suhu pada saat perlakuan dengan menggunakan thermometer. Pengukuran dilakukan pada saat pemasangan perangkapnyamuk di dalamLaboratorium. Pengukuran suhu dilakukan padatanggal 24 juni 2015 sebanyak 3 kali dalam 24 jam padapukul 13.30, 18.30, 07.30. Hasil pengukuran suhuyaitu $24^{\circ} \mathrm{C}, 23^{\circ} \mathrm{C}, 21^{\circ} \mathrm{C}$. Suhu tersebut kurang cocok untuk perkembangan nyamuk karena suhu optimum untuk perkembangan nyamuk berkisar antara $25^{\circ} \mathrm{C}-27^{\circ} \mathrm{C}$. Hasil pengukuran suhuminimum diperoleh pada jam ke 3 sebesar $21^{\circ} \mathrm{C}$. Hal itu disebabkan karena pengaruh cuaca. Sedangkan suhumaksimum diperoleh pada jam ke 1 sebesar $24^{\circ} \mathrm{C}$. Pada saat pengukuran kondisi cuaca seringkali tidak menentu sehingga suhu tidak stabil. 
Nyamuk adalah binatang berdarah dingin, oleh sebab itu proses metabolisme dan siklus kehidupannya tergantung pada suhu lingkungan. Nyamuk tidak dapat mengatur suhu tubuhnya sendiri terhadap perubahan-perubahan di luar tubuhnya. Suhu rata-rata optimum untuk perkembangan nyamuk adalah $25^{\circ} \mathrm{C}-27^{\circ} \mathrm{C}$. Nyamuk dapat bertahan hidup pada suhu rendah, akan tetapi proses metabolisme menurun atau bahkan terhenti bila suhu turun sampai dibawah suhu kritis dan pada suhu yang sangat tinggi akan mengalami perubahan fisiologisnya. Pertumbuhan nyamuk akan terhenti sama sekali bila suhu kurang dari $10^{\circ} \mathrm{C}$ atau lebih dari $40^{\circ} \mathrm{C}$. Toleransi terhadap suhu tergantung pada spesies nyamuknya, tetapi pada umumnya suatu spesies tidak akan bertahan lama bila suhu lingkungannya meninggi $5^{\circ} \mathrm{C}-6^{\circ} \mathrm{C}$ diatas batas dimana spesies secara normal dapat beradaptasi. (Ditjend PPM \& PL, 2004, h.8).

2. Kelembaban Udara

Kelembaban udara diukur menggunakan hygrometer, pengukuran dilakukan pada saat pemasangan dan pemantauan jumlahnyamuk Aedesaegypti yang terperangkap dalam perangkapnyamuk selama 3 kali dalam 24 jam padapukul 13.30, 18.30, 07.30 WIB. Pada saat pengukuran kondisi cuaca tidak menentu. Semakin tinggi suhu udara pada lokasi penelitian, maka kelembabannya semakin rendah.

Hasil pengukuran kelembaban minimum sebesar $80 \%$ sedangkan kelembaban maksimum sebesar $90 \%$, hasil tersebut sangat cocok untuk perkembangan nyamuk. Pengukuran kelembaban dilakukan di tempat peletakan kurungannyamuk.Pengaruh cuaca mengakibatkan naiknya kelembaban nisbi udara,pada kelembaban yang tinggi nyamuk menjadi lebih aktif.

Kelembaban udara adalah banyaknya kandungan uap air dalam udara yang biasanya dinyatakan dalam persen (\%). Jika dalam udara ada kekurangan air yang besar, maka udara ini mempunyai daya penguapan yang besar. Sistem pernafasan pada nyamuk adalah menggunakan spiracle. Adanya spiracle yang terbuka tanpa ada mekanisme pengaturannya, pada waktu kelembaban rendah akan menyebabkan penguapan air dari dalam tubuh nyamuk yang dapat mengakibatkan keringnya cairan tubuh nyamuk. Salah satu musuh nyamuk adalah penguapan. Pada kelembaban kurang dari $60 \%$ umur nyamuk akan menjadi pendek sehingga tidak cukup untuk siklus pertumbuhan parasit di dalam tubuh nyamuk. (Ditjend PPM \& PL, 2004, h.9)

3. Intensitas Cahaya

Intensitas cahaya diukur menggunakan Luxmeter, pengukuran dilakukan pada saat pemasangan dan pemantauan jumlahnyamuk Aedesaegypti yang terperangkap dalam perangkap nyamuk selama 3 kali dalam 24 jam pada pukul 13.30, 18.30, 07.30 WIB. Pada saat pengukuran kondisi cuaca tidak menentu.

Hasil pengukuran intensitas cahaya minimum sebesar 0 lux sedangkan pencahayaan maksimum sebesar 211,7 lux, hasil tersebut dapat dilihat bahwa pada saat pengukuran intensitas pencahayaan pada malam hari dan siang hari sangat berbeda, karena pada malam hari kondisi lokasi penelitian gelap hanya terdapat pencahayaan buatan yang tidak begitu terang, dan pada waktu malam hari nyamuk Aedes aegypti akan lebih pasif karena dalam kondisi istirahat (resting).

Pencahayaan juga berpengaruh terhadap aktivitas dan tempat peletakan telur nyamuk Aedes aegypti. Nyamuk tersebut cenderung menyukai tempat yang teduh, tidak langsung terkena sinar matahari.

4. Jumlah Nyamuk Aedes aegypti yang terperangkap Pada Perangkap Nyamuk

Jumlah keseluruhan nyamuk Aedes aegypti yang terperangkap pada semua perangkap yang berisi atraktan fermentasi air tebu konsentrasi $5 \%$, $10 \%, 20 \%, 40 \%$ dan $0 \%$ (air bersihdanragi sebagai kontrol) dengan letak pemasangan perangkapnyamukdi dalam kurungan nyamuk didapatkan 4 ekor $(13,3 \%)$. Hasil perolehan nyamuk kemudian dikelompokan berdasarkan jenis atraktan dan kurungan nyamuk seperti pada pembahasan di bawah ini :

a. Berdasarkan Jenis Atraktan

Dari hasil pengamatan yang dilakukan selama 3 kali dalam24 jam, didapatkan hasil jumlah nyamuk Aedes aegypti yang terperangkap pada perangkap berisi air tebu dengan konsentrasi 5\% sebanyak 1ekor $(3,33 \%)$ dan yang masuk pada perangkap nyamuk berisi air tebu $10 \%$ sebanyak lekor $(3,33 \%)$, pada perangkap nyamuk berisi air tebu20\% sebanyak 0 ekor $(0 \%)$, dan pada perangkap nyamuk berisi air tebu $40 \%$ sebanyak 2 ekor $(6,66 \%)$, sedangkan pada perangkap nyamuk konsentrasi 0\% (air bersih dan ragi sebagai kontrol) sebanyak 0 ekor $(0 \%)$.

Fermentasi air tebu dengan konsentrasi $40 \%$ memiliki daya tarik (atraktansi) yang lebih kuat dibandingkan dengan fermentasi air tebu dengan konsentrasi 5\%, 10\%, 20\% dan $0 \%$ (air bersih dan ragi sebagai kontrol).

Semakin meningkatnya kepekatan fermentasi air tebu maka jumlah nyamuk yang terperangkap semakin banyak. Hal itu disebabkan karena meningkatnya kadar ammonia dan $\mathrm{CO}_{2}$ yang dihasilkan dari setiap bertambahnya pengenceran.

Ammonia dan $\mathrm{CO}_{2}$ yang terdapat pada fermentasi air tebu menimbulkan bau yang khas yang dapat berfungsi sebagai atraktan 
nyamuk. Bau yang khas tersebut ditangkap oleh antenna nyamuk dimana terdapat sensilla yang mengandung satu atau beberapa saraf bipolar penciuman atau dikenal dengan ORNs (Olfactory Receptor Neurons). ORNs berada pada ujung dendrit dan ujung akso untuk mendeteksi bahan-bahan kimia. Saraf sensorik ini menghantarkan impuls kimia berupa respon elektris dari perifer ke lobus antenna yang merupakan tempat penghentian pertama dalam otak. Setelah masuk ke dalam sendillum melewati pori kutikula molekul bau tersebut melewati cairan lymph menuju dendrit. Kebanyakan molekul bau sangat mudah menguap dan relatif hidrofob.

Bau berikatan dengan OBPs (Odorant Binding Proteins) kemudian melewati cairan lymph. Selain sebagai pembawa, OBPs juga bekerja melarutkan molekul bau tersebut dan bertindak dalam seleksi informasi penciuman. Ketika kompleks bau OBPs mencapai membran dendrite, bau akan berikatan dengan reseptor transmembran, kemudian ditransfer ke permukaan membran intracellular. Selanjutnya impuls elektrik tersebut disampaikan ke pusat otak yang lebih tinggi dan berintegrasi untuk menghasilkan respon tingkah laku yang tepat. (Jacquin and Jolly, 2004)

Adanya $\mathrm{CO}_{2} \quad$ yang terkandung padafermentasiragidan air tebu, dianggap oleh nyamuk sebagai $\mathrm{CO}_{2}$ yang dihasilkan dari proses respirasi makhluk hidup karena nyamuk tertarik dengan aktivitas makhluk hidup dengan cara mendeteksi keberadaan $\mathrm{CO}_{2}$ pada saat bernafas, radiasi tubuh dan bau keringat. Dengan demikian bagian tubuh host yang banyak mengandung darah akan menjadi sasaran empuk nyamuk untuk di hisap darahnya. (Santjaka, A 2013, h.36)

Berdasarkan hasil penelitian yang dilakukan oleh peneliti, fermentasiair tebu konsentrasi $40 \%$ yang dilihat secara visual keruh dan berbau mengasilkan nyamuk Aedes aegypti yang terperangkap 2ekor $(2,85 \%)$.

b. Berdasarkan KurunganNyamuk

Perangkap nyamuk yang berisi fermentasi air tebu dengan konsentrasi 5\%, 10\%, 20\%, $40 \%$ dan $0 \%$ (air bersih dan ragi sebagai kontrol) diletakan secara acak di dalam kurungan nyamuk selama 24 jam. Selama 24 jam di pantau sebanyak 3 kali untuk mengetahui jumlah nyamuk yang terperangkap di dalam perangkap nyamuk.

Jumlah nyamuk Aedes aegypti pada perangkap nyamuk yang berada di dalam kurungan nyamuk 1 dengan air tebu konsentrasi $40 \%$ sebanyak 1ekor $(3,33 \%)$, pada perangkap nyamuk di dalam kurungan nyamuk 2 dengan konsentrasi $10 \%$ dan $40 \%$ sebanyak masing - masing 1 ekor (3,33\%), sedangkan dalam kurungan nyamuk 4 dengan air tebu konsentrasi 5\% sebanyak 1 ekor $(3,33 \%)$.

\section{IV.KESIMPULAN}

Jumlah nyamuk Aede saegypti yang terperangkap pada perangkap nyamuk yang berisi atraktan fermentasi air tebu dengan konsentrasi 5\% sebanyak 1 ekor $(3,33 \%)$, konsentrasi $10 \%$ sebanyak 1 ekor $(3,33 \%)$, konsentrasi $20 \%$ sebanyak 0 ekor $(0 \%)$, konsentrasi $40 \%$ sebanyak 2 ekor $(6,66 \%)$ danpada air bersihdanragi (sebagai kontrol) sebanyak 0 ekor $(0 \%)$. Tidak ada perbedaan jumlah nyamuk Aedes aegypti yang terperangkap pada atraktan air tebu konsentrasi 5\%, 10\%, 20\%, 40\% dan 0\% (air bersih dan ragi sebagai kontrol). Tidak terdapat konsetrasi fermentasi air tebu yang efektif, di antara konsentrasi yang ada konsentrasi $40 \%$ yang paling banyak jumlah nyamuk yang terperangkap.

\section{DAFTARPUSTAKA}

Anonim,(1984) Cara Pengolahan Tebu Menjadi Gula Kristal Untuk Para Petani Tebu Rakyat, Seri X,Surabaya: PT. Perkebunan XXI-XXII (Persero)

Aris Santjaka, (2013), Malaria (Pendekatan Model Kausalitas), Yogyakarta : Nuha Medika

Cecep Dani Sucipto,( 2011), Vektor Penyakit Tropis, Yogyakarta : Gosyen Publishing

Chasan Sudjain Kusniadi, (2006), Pengendalian Vektor Dan Binatang Pengganggu, Makasar : Jakarta

Departemen Kesehatan RI,( 2004), Pedoman Ekologi dan Aspek Perilaku Vektor, Jakarta : Ditjend : PPM \& PL

Departemen Kesehatan R.I. Direktorat Jenderal Pengendalian Penyakit Dan Penyehatan Lingkungan (DIT.JEN.PP\&PL),( 2007), Ekologi dan Aspek Perilaku Vektor, Jakarta : Ditjen P2PL

Departemen Kesehatan RI, (2009), Rencana Pembangunan Jangka Panjang Bidang Kesehatan (2005-2025), Jakarta : Depkes RI

Djamaluddin, Ramlan, (2013), Petunjuk Praktis Penulisan Penelitian Eksplanatif, Purwokerto : UPT Percetakan Unsoed dan Penerbitan

Djoni Djunaedi, (2006), Demam Berdarah, Malang : UMM Press 
Dwidjoseputro, (1989), Dasar - Dasar Mikrobiologi, Surabaya : Djambatan

Hidayat, A. Aziz Alimul, (2007), Metode Penelitian Kebidanan dan Teknik Analisis Data, Jakarta : Salemba Medika

I Wayan Supartha, (2008), Pengendalian Terpadu Vektor Virus DBD, Aedes aegypti dan Aedes albopictus,http://www.linkpdf.com/download/ $\mathrm{dl} /$ pengendalian-terpadu-vektor-virusdemamberdarah-dengue-aedes--.pdf,diaksespada tanggal 11 November 2014

Jacquin and Jolly, (2004), Insect Olfactory Receptors Constribution of Molecular Biology to Chemical Ecology, http://www.science.uva.nl diakses pada tanggal 4 juni 2015

Kementerian Kesehatan RI, (2013), Profil Data Kesehatan Indonesia (2012), at http://www.depkes.go.id/index.php?vw=2\&pg =Profil Kesehatan Nasional diakses pada tanggal 15 November (2014) pukul 10.30 WIB

Okto Sudaryono, (2011), Efektifitas Larutan Gula Jawa, Larutan, Larutan Gula Pasir Dan Larutan Gula Batu Guna Menangkap Nyamuk Aedes aegypti Menggunakan Ovitrap Di Kelurahan Karang Pucung Kecamatan Purwokerto Selatan Kabupaten Banyumas: Kementerian Kesehatan RI Politeknik Kesehatan Semarang Jurusan Kesehatan Lingkungan Purwokerto
Ririh Yudhastuti, (2011), Pengendalian Vektor Dan Rodent, Surabaya : Pustaka Melati

Sayono, (2008), Pengaruh Modivikasi Ovitrap Terhadap Jumlah Nyamuk Aedes Yang Terperangkap, Tesis : Universitas Diponegoro

Soegeng Soegijanto, (2006), Demam berdarah Dengue, Surabaya : Airlangga University Press

Sofiyatul Mardiyah, (2014), Pengaruh Berbagai Konsentrasi Air Rendama Jerami Sebagai Atraktan Terhadap Jumlah Telur Nyamuk Aedes sp Yang Tertangkap di Rw 04 Kelurahan Karang Pucung Kecamatan Purwokerto Selatan Kabupaten Banyumas: Kementerian Kesehatan RI Politeknik Kesehatan Semarang Jurusan Kesehatan Lingkungan Purwokerto

Soekidjo Notoatmodjo, (2010), Metodologi Penelitian Kesehatan, Jakarta : Rineka Cipta

Sutaryo, (2004), Dengue, Jogjakarta : UGM

Tri Cahyono, (2013), Pedoman Penulisan Proposal Penelitian dan Karya Tulis Ilmiah/Skripsi (Edisi Revisi Ketiga), Purwokerto : Kementrian Kesehatan RI Politeknik Kesehatan Kemenkes Semarang Jurusan Kesehatan Lingkungan Purwokerto

Widoyono, (2011), Penyakit Tropis Epidemiologi, Penularan, Pencegahan \& Pemberantasannya, Jakarta : Erlangga 